\title{
Design Mathematical Activity in Mathematics Classroom: Decimal Number
}

DOI: https://doi.org/10.47175/rielsj.v2i3.293

\section{| Sunti Bunlang ${ }^{1,2}$ | \\ ${ }^{1}$ Mathematics Education \\ Program, Faculty of \\ Education, Khon Kaen \\ University, Khon Kaen, \\ Thailand \\ ${ }^{2}$ Institute for Research and Development in Teaching Profession for ASEAN, Khon Kaen University, Khon Kaen, Thailand}

sunbun@kku.ac.th, Inprasitha_crme@kku.ac.th, changsri_crme@kku.ac.th

\begin{abstract}
The research was aimed to investigate six-lesson study team members in designing mathematical activities to develop students' mathematization using Open Approach in the second step of the Lesson Study process in teaching decimal numbers. A total of 16 Grade 4 students participated as the target group. Three instruments were used namely lesson plans, student worksheets, and observation field notes. Researchers employed ethnographic research design to study how the mathematical activities could assist students to develop their mathematical ideas from the real world to the mathematical world through a flow of lessons over the four stages of the Open Approach along with the Lesson Study process. The research results revealed that a series of five research lesson plans encompassing various mathematical activities were successfully encouraging students to elaborate their ideas and transmitting their ideas from the realworld to the mathematical world using semi-concrete aids. Moreover, the results of using the Open Approach have been proved to be relevant as students demonstrated their mathematization in fostering their mathematical thinking to transform their ideas smoothly. Therefore, designing mathematical activities is important to cultivate students mathematical thinking in problem-solving instantaneously. A limitation of the research was identified when the Lesson Study team members were reflecting on the teaching practice. This is because they found that the unclear illustration in the student worksheets has raised confusion. In conclusion, the overall results of this research have contributed significantly to our recognition of the practicality of Open Approach treatment in the Lesson Study process in developing students' mathematization through their participation in mathematical activities.

KEYWORDS

decimal number; Lesson Study; mathematical activities mathematization; Open Approach.
\end{abstract}

\section{INTRODUCTION}

Mathematics is not only about numbers, but it is about the varying degrees of creativity presented to students who participate in mathematics (Bevan \& Capraro, 2021). Therefore, their presence in the mathematics classroom largely depends on diverse instructional approaches that providing a channel for students to be creative in their thinking (Bevan \& Capraro, 2021). Their research results showed that posing problems in the mathematics classroom can enhance students' learning experiences and allow them to produce problems in a realistic context. As a result, Tomlinson (2000) emphasized differentiated learning that providing a zone of proximal development (Vygotsky in Daniels, 2016), and 
student ownership for their own learning. This is supported by Moonsri, Inprasitha, and Changsri (2021) that mathematics teachers need to possess skills in anticipating and interpreting students' ideas and methods of thinking about mathematics. $t$ is necessary to create a high school mathematics curriculum that has a good chance of providing students with the knowledge and skills that are needed to ensure success at university and career lives (James, 2016) in Chikusvura (2021).

Generally, mathematics teachers in Thailand who implemented conventional method by preparing and teaching lesson plans, checking the assigned homework, and prescribing exercise were found irrelevant in current teaching context (Inprasitha, 2015; Kaewdang, 2000; Khammani, 2012). Pyper (2021) stated that mathematics should be learned in real experience including practical and conceptual learning environments. This means that the process of learning in a relevant environment is more important than the final product of the learning such as reaching a correct answer (Pyper, 2021).

Stigler and Hiebert (1999) compared mathematics teaching across different countries that are considered to be good and quality teaching. They found a positive outcome of the Lesson Study (LS) model after they investigated the outstanding performance of Japanese students on various international mathematics tests to their high-quality classroom teaching. Lewis (2000) defined LS as the overall process of instructional improvement, in which teachers collaboratively plan, observe, and evaluate research lessons. Murata (2011) mentioned that the collaborative, classroom-based, and practice-oriented is the key feature of LS.

On the other hand, the ideas of Open Approach (OA) recommended by Nohda (2000) are to encourage students to pursue their own means of life, has their entire cognizance and frame to contribute to their community with bursting strength based on mathematical sense, knowledge, skills, and the ways of thinking. This is further supported by Sambová and Tichá (2016) who emphasized that students must solve an open-ended problem using various methods to examine the problem mathematically, exploring numerous methods to the given problem situation, and posing various innovative solutions as a current innovative way of teaching mathematics.

These two innovations, namely LS and OA have been adapted in the Thailand context by Inprasitha respectively $(2004,2009)$ for improving a paradigm of teachers' teaching practices. A Thailand LS Model by incorporating OA treatment in the second step of the LS process was created by Inprasitha (2011), as elucidated in Figure 1. The LS is emphasizing on improving the collaborative working of teachers while the OA is emphasizing on individual differences, particularly in each student's thinking development. The LS process consists of three steps: (i) Collaboratively design research lesson (Plan); (ii) Collaboratively observe research lesson (Do), and (iii) Collaboratively reflect on teaching practice (See) (Inprasitha, 2004). The OA is comprised of four stages: (i) Posing open-ended problem; (ii) Students' self-learning; (iii) Whole class discussion and comparison, and (iv) Summarize through connecting students' mathematical ideas emerged in the classroom (Inprasitha, 2009). 


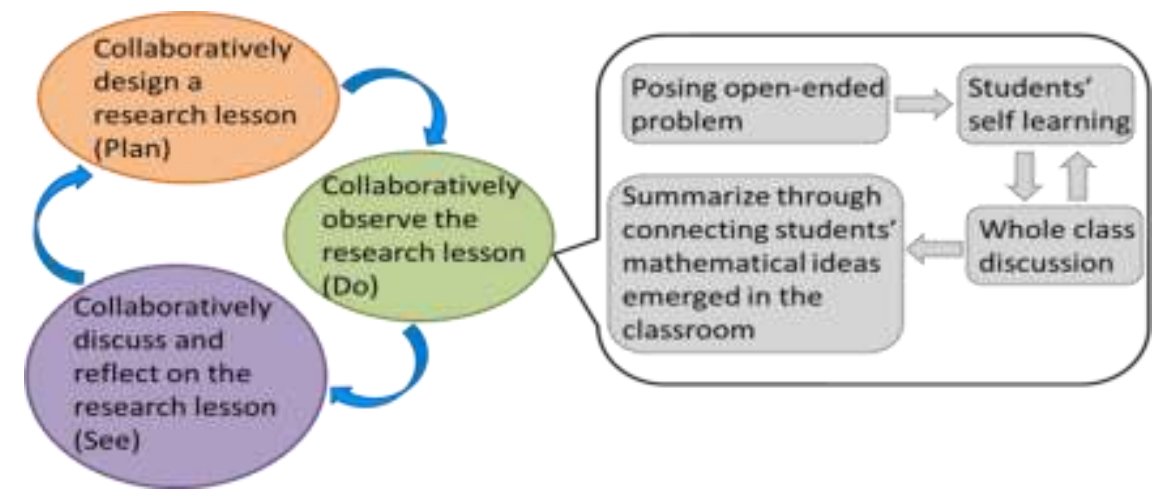

Figure 1. Thailand LS Model

\section{RESEARCH METHODS}

\section{Research Participants}

The LS team was formed including three full-time teachers who adopted and utilized the Thailand LS Model for more than 14 years in the research school, a researcher from the Institute for Research and Development in Teaching Profession for ASEAN, and two postgraduate Mathematics Education program students from Faculty of Education, Khon Kaen University. Three of them have more than four years of experience in designing mathematical activities, giving a total of six members to the LS team. Besides, a total of 16 Grade 4 students from the research school were purposively selected because this group of students has attended their mathematics lessons using the Thailand LS Model for the past four years. The rationale for choosing this research school is because it is our pioneer project school of Education Equality Project and all teachers have participated in the teacher professional training organized by the Centre for Research in Mathematics Education, Khon Kaen University from time to time.

\section{Research Design}

The researchers employed ethnography research design as a type of qualitative approach to gather the collection of observations and documentary data. This research design is found appropriate because it can yield detailed and all-inclusive accounts of different social phenomena including actions, behavior, interactions, and beliefs (Reeves, Peller, Goldman, \& Kitto, 2013). Owing to researchers had to involve in the fieldwork actively with the local school context that was studying, the research design was used to observe the teaching practices by applying OA and LS innovations and how these innovations could affect students' mathematization (Reeves et al., 2013).

\section{Research Procedure and Instruments}

Researchers invited the headmaster of the research school using personal contacts to discuss the project. According to Lundbäck and Egerhag (2020), it was important to acknowledge the headmaster of the school regarding the research involvement and their willingness to participate, particularly the LS process which is quite time-consuming. The LS team members were informed about the Thailand LS Model and the importance of observing each other in the teaching situation. The research procedure was comprised of three phases in parallel with the three steps of the LS process.

In the Plan step, the LS team members were designing the mathematical activities for five lesson plans of decimal numbers in detail, including the different approaches based on the curricular expectations and their knowledge of how students learn after referring to the 
project mathematics textbook - Thai version of a Japanese mathematics textbook. Besides, they also planned for semi-concrete aids and related mathematical activities that focus on students' real-world experiences. This is followed by the Do step as the second phase, where the other LS team members except the teacher who was teaching observed the implementation of the research plans that they developed in the first phase. During the observations, they would fill in the field notes to indicate students' mathematization. Each lesson lasted approximately 50 minutes to one hour. After the completion of each research lesson, all the LS team members would meet together to reflect on the teaching that they had observed as the final phase of the procedure.

All five research lessons were audio and video recorded as they could be used by researchers to review each research lesson several times to avoid missing any phenomena that might have been overlooked during the second phase. The research instruments utilized in this research included five research lesson plans, field notes, and student worksheets. The audio and video recordings were the additional instruments used for missing data from the three research instruments. In short, the research procedure was started with collaborative lesson planning, followed by collaborative classroom teaching and observation, and ended with the collaborative reflection on the research lesson.

\section{Data Collection and Data Analysis}

The obtained data from classroom observation, student worksheets, and field notes were imported into NVivo and transcribed verbatim. The audio and video recordings of lesson observations were coded for emerging themes, and then the nodes were explored to search for characteristics of students' mathematization. Besides using content analysis to analyze the data, data triangulation was employed too. For example, field notes written during the lesson observations, student worksheets, and the transcript of audio and video recordings were systematically triangulated.

\section{RESULTS AND DISCUSSION}

\section{Results from Step 1 of LS: Collaboratively Design Research Lesson (Plan)}

The research was started by LS team members who designed five lesson plans in sequence to make sure that appropriate progress of students' mathematization from real-world to mathematical world was considered. When designing the lesson plan, the LS team members must assimilate the overall development of the particular topic content that was 'Decimal Number' as part of the Grade 4 mathematical syllabus, besides referring to the content domain of the Japanese translated textbook. Moreover, they also focused on students' mathematical activities, including listening, direct instruction, reading, writing, discussing, illustrating, conducting experiments so that teachers could create an interesting mix of activities that were likely to have high participation levels. At the same time, the LS team members must stipulate mathematical activities according to the flow of lessons by taking into account the comprehensive development of students' mathematization using OA treatment. In this method, the possible problem solutions were planned through mathematical activities (Tall, 2014). Figure 2 shows the LS team were designing the five research lesson plans collaboratively. 


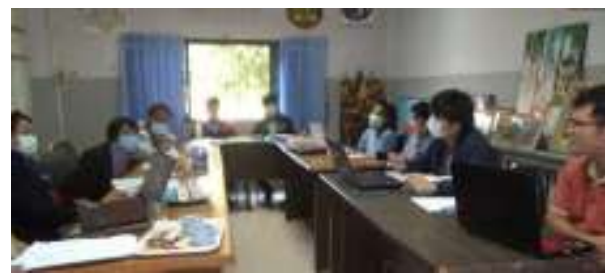

Figure 2. LS team was designing a joint research lesson plan

The three full-time teachers from the research school were labeled as (LSTM1, LSTM2, LSTM3) respectively. A researcher from the Institute for Research and Development in

Teaching Profession for ASEAN was labeled as LSTM4, and the two post-graduate Mathematics Education program students from the Faculty of Education were labeled as LSTM5 and LSTM6. Table 1 demonstrates the observation results during the Plan step of LS.

Table 1. Designing research lesson plan

\begin{tabular}{|l|l|}
\hline Speaker & Behavioral observation \\
\hline LSTM1 & $\begin{array}{l}\text { Refer to page 29, the mathematical activity suggested in the Japanese } \\
\text { translated textbook indicating to ask students to pour water into the } \\
\text { containers. Let the students see the vagueness of the excess space } \\
\text { before they compare. }\end{array}$ \\
\hline LSTM5 & $\begin{array}{l}\text { Can we put water in the two glasses as the equal volume that is 1dl? } \\
\text { This will be our first teaching order at the beginning of the lesson. }\end{array}$ \\
\hline LSTM2 & $\begin{array}{l}\text { To me, students' real-world experience would be the amount of water } \\
\text { that they pour into the three cups. The semi-abstract aids should be the } \\
\text { creation of scale and dividing smaller units of the scale because they } \\
\text { have learned fractions already. Require students to write the amount of } \\
\text { water as the decimal number is our intention to transform students' } \\
\text { ideas into the mathematical world. }\end{array}$ \\
\hline LSTM3 & $\begin{array}{l}\text { Let students fill up the three containers but not full, leave some excess } \\
\text { space to show that there is still have something for students to identify } \\
\text { by themselves. }\end{array}$ \\
\hline LSTM4 & $\begin{array}{l}\text { We should create the picture in the student worksheets as our main } \\
\text { media. The amount of water that students need to measure again and } \\
\text { again until they get 2.6 dl. }\end{array}$ \\
\hline LSTM6 & $\begin{array}{l}\text { When the students firstly pour the water up to the point to match the } \\
\text { picture shown in the student worksheets, they are probably moving } \\
\text { from real-world experience to a semi-abstract position. }\end{array}$ \\
\hline LSTM1 & $\begin{array}{l}\text { For the second flow of lessons, we should generate students' } \\
\text { mathematical concepts shifting gradually from real-world experience to } \\
\text { the mathematical world, as they have measured the volume of water } \\
\text { from without having scale up to having scale. When students manage } \\
\text { to reach the decimal point 2.6, they will understand the additional } \\
\text { decimal number as .6. Students are expected to get the meaning out of } \\
\text { it. }\end{array}$ \\
\hline
\end{tabular}

Besides, they needed to understand many students' ideas as possible, to sophisticate the ideas in mathematical activities by means of students' discussions with their peers and/or teachers' assistance because they employed OA. The research lesson plans must design to encourage students' self-government in elaborating the activity mathematically. Researchers found that the teaching by OA has to design with the intention to open up 
students' hearts toward mathematics, so-called mathematization. The five research lesson plans were designed according to the flow of lessons from students' real world, followed by using semiconcrete aids to connect students' initial ideas to their mathematical world (Inprasitha, 2017) as shown in Figure 3.

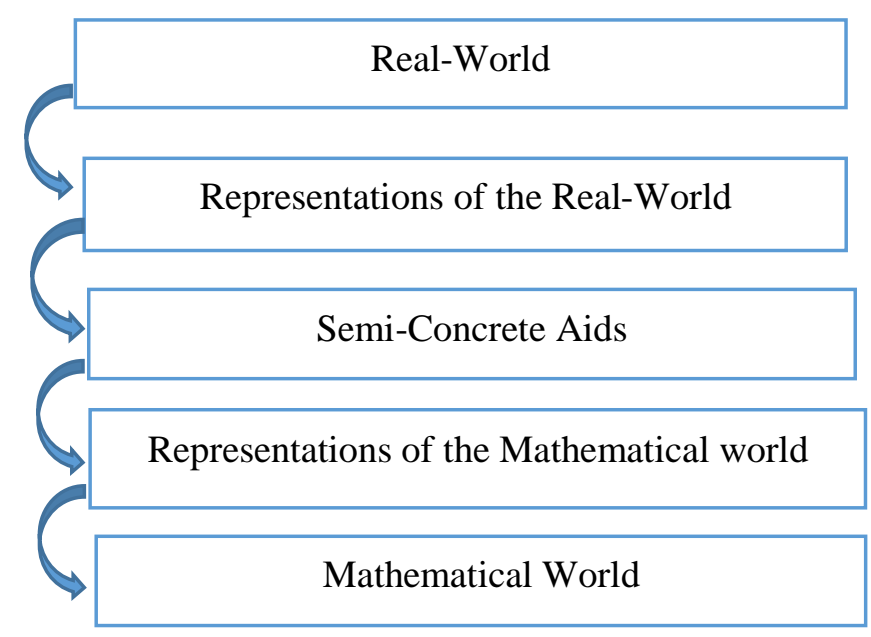

Figure 3. The flow of lessons (Inprasitha, 2017)

Student's ability to use figures or any other materials to communicate their real experience that associated with the problem situation about the decimal numbers was taken into account as representing students' real world. The research lesson plan was designed to allow to observation of the amount of water in each of the three containers. The designed mathematical activity aimed to trigger students' real experience by pouring water into three types of containers, namely tea glass, coffee mug, and water glass with three different volumes such as $2 \mathrm{dl}, 2.6 \mathrm{dl}$, and $2.1 \mathrm{dl}$ (refer Figure 4). Figure 4 displays the planned mathematical activity to represent the real world of students.

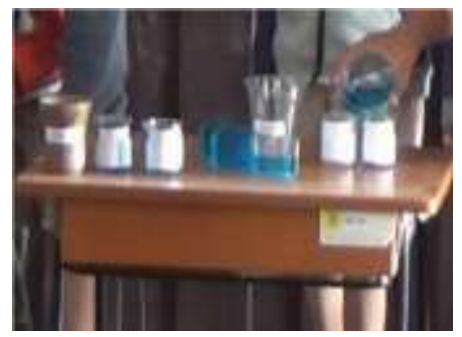

Figure 4. Representations of the real-world

This is then followed by using semi-concrete aids for students to emerge their ideas to solve the problem situation. The LS team members designed the mathematical activity by requiring students to do their predictive position of water in the three containers so that students could connect their ideas using semi-concrete aids. For example, Figure 5 shows the concept of quantity regarding how many cups of water can be measured by each container for students to explore further. At this stage, students were expected to connect their real-world experience, coupled with the semi-concrete aids to ease their ability to solve the problem. 


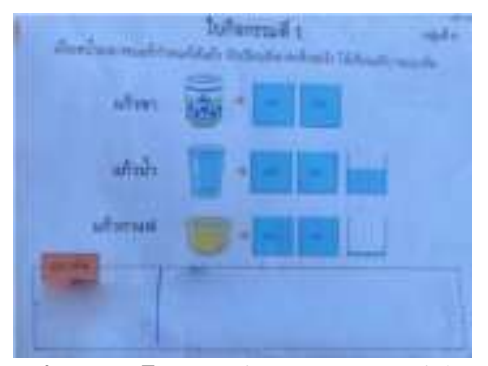

Figure 5. Semi-concrete aids

Another mathematical activity to show the sequential progress of the research lesson was begun by allowing students to see and predict the quantity of water (representation of realworld). At this time, students developed their ideas by linking what they visualized to their sense of excess as elucidated in Figure 6.

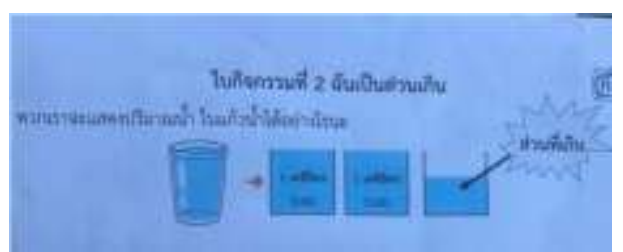

Figure 6. The mathematical activity of students' ideas development

Results of the research lesson plan indicated that the LS team members designed the mathematical activity by projecting students to use semi-figurative media as semi-concrete aids. For example, students are challenged to draw or write 10 equal parts to show that they understood the fraction and the advantages of dividing units into 10 and trying to use the mathematical concepts to solve the problem. The results from student worksheets showed that decimal with basic units in dividing the dl unit to be a measuring tool with a height of 10 centimeters and a ruler as illustrated in Figure 7 showed the students' ideas development or so-called mathematization.

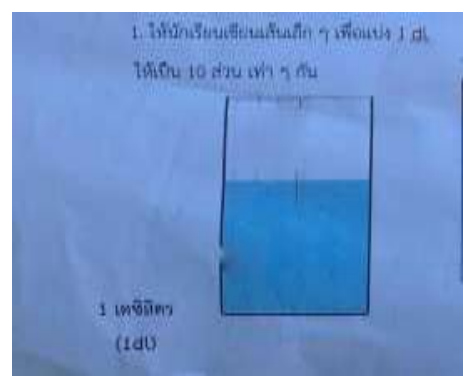

Figure 7. Results of student worksheets

The representations of the mathematical world were the final stage of students' mathematization so that the designed mathematical activity could assist students to use numbers and symbols to communicate their ideas meaningfully. The results showed that the LS team members designed the mathematical activity in such a way that students were required to express the ambiguous number with $2 \mathrm{dl}$ and more. Figure 8 shows the student worksheet whereby students must indicate the numerical position in each column of the worksheet in either less or more than $2 \mathrm{dl}$ of filled water. 


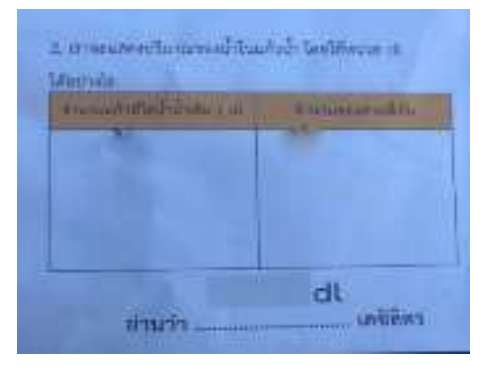

Figure 8. Results of representations of the mathematical world

\section{Results from Step 2 of LS: Collaboratively Observe Research Lesson (Do)}

After the research lesson plan was designed by the LS team member, one of the LS team members conducted the lesson according to what had been planned. The other LS team members played their roles as supportive observers. The flow of lessons along with the four stages of OA was operated mainly to identify empirical evidence of students' mathematization while they participated to solve problems related to decimal numbers. The 16 students were labeled as S1 to S16.

(i) Posing an open-ended problem

The teacher started his teaching activities by reviewing the students' prior knowledge. He then posed an open-ended problem situation by showing a picture with two containers and acquired students to determine the quantity of each container. Therefore, students must develop their ideas or conceptual understanding of the problem situation based on their prior experience in their real-world as shown in Figure 9. At this moment, students were given opportunities to access the problem so that they could communicate their real experiences. In other words, students participated in a mathematical activity that provided by the teacher to represent their real world.

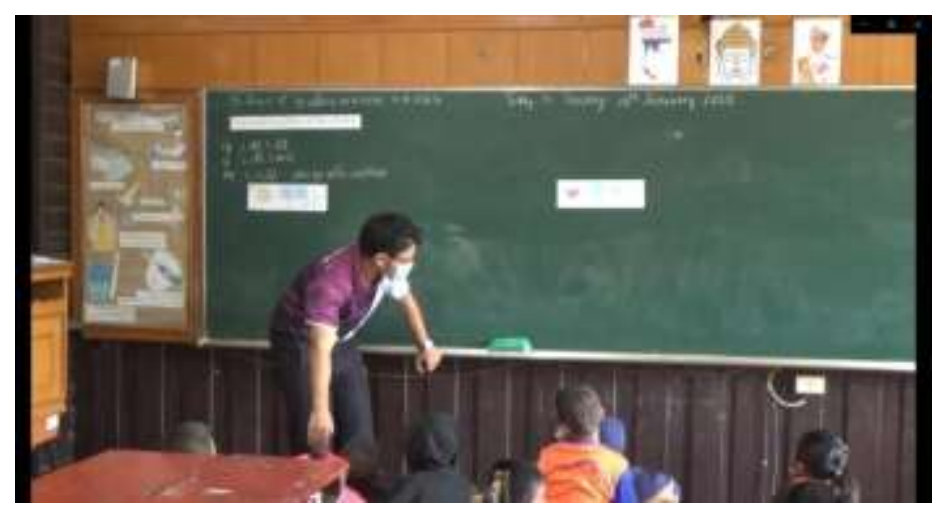

Figure 9. The teacher is posing an open-ended problem situation

The teacher was encouraged to present the open-ended problem situation in the form of commands and clues such as "How much dl of water is in the container?". This is to inspire students to learn independently as shown in Figure 10. Table 2 shows the results derived from the field notes. 


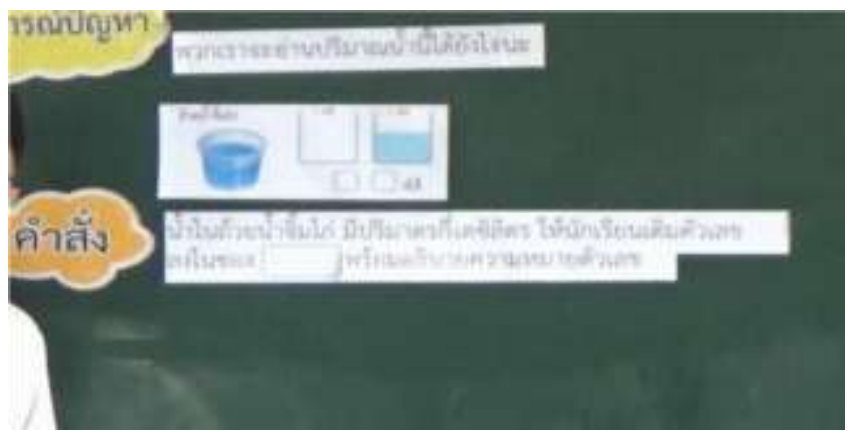

Figure 10. Open-ended problem situation in the form of commands and clues

Table 2. Results of field notes

\begin{tabular}{|c|c|c|c|}
\hline OA & Students' ideas & Mathematization & $\begin{array}{c}\text { Mathematical } \\
\text { ideas }\end{array}$ \\
\hline $\begin{array}{c}\text { Posing an } \\
\text { open- } \\
\text { ended } \\
\text { problem } \\
\text { situation }\end{array}$ & $\begin{array}{c}\text { Students read a wide range } \\
\text { of amounts of } \\
\text { water in the container } \\
\text { that exceeds units such as } \\
2.1 \mathrm{dl}, 2 \mathrm{dl}, 1 \mathrm{ml}, 2 \mathrm{dl}, 1 \mathrm{dl} .\end{array}$ & $\begin{array}{c}\text { Visualization of the } \\
\text { amount of water as } \\
\text { a decimal number }\end{array}$ & $\begin{array}{c}\text { Write the amount of } \\
\text { water in the } \\
\text { container as a } \\
\text { decimal number }\end{array}$ \\
\hline
\end{tabular}

(ii) Students' self-learning

The students read the problem situation and its related instruction; they were encouraged to discuss it with their peers during the self-learning stage. At the same time, the teacher distributed the student worksheets and semi-concrete aids for them so that they could solve the problem together as displayed in Figure 11 and Figure 12. As a result, researchers found that students' self-learning can assist the students to develop their mathematical concepts gradually through their participation in mathematical activities.

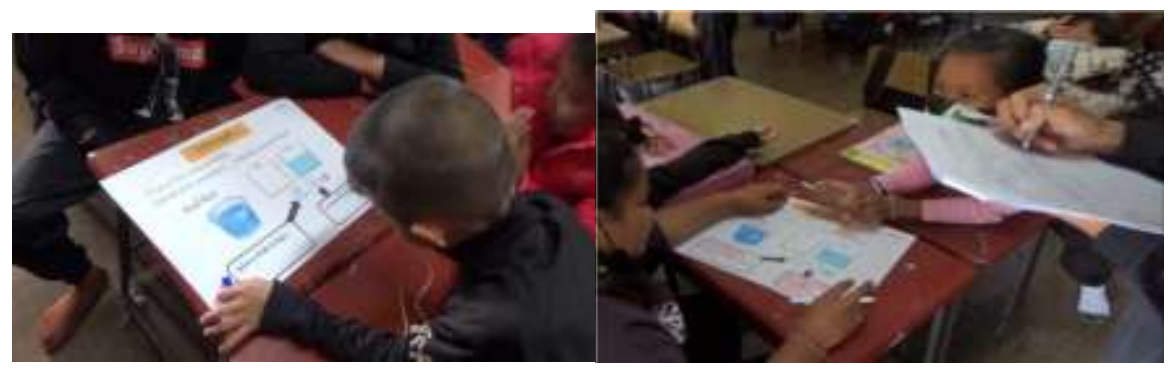

Figure 11. Students discussed the decimal number of 0.6

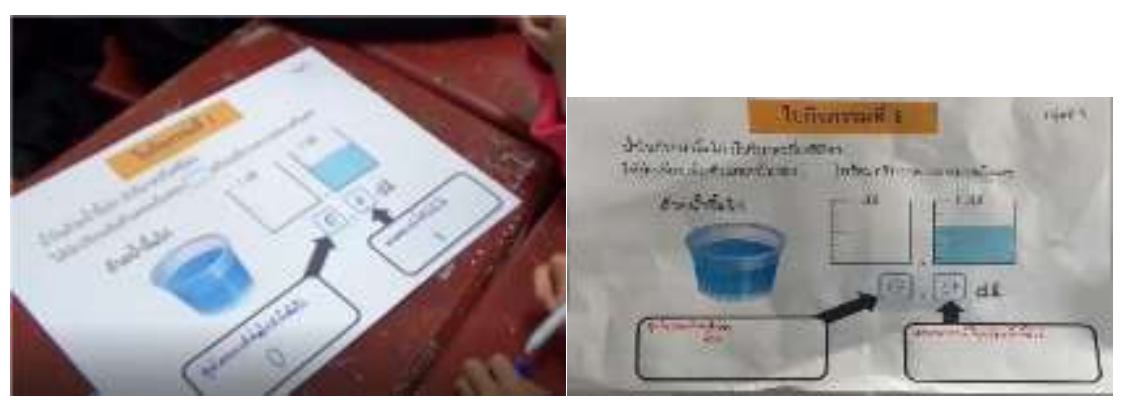

Figure 12. Students' ideas between zero and six in two containers 
(iii) Whole class discussion and comparison

After the students have completed their worksheets, the teachers selected the groups with different ways of problem-solving to explain how they solve the problem. At this stage, students were inspired to learn collaboratively, and the teacher provided sufficient opportunities for their peers to give their points of view too. The observation results revealed that students' ideas are developed gradually when they are involved in mathematical activities. The teacher's role at this stage was to facilitate their students' conceptual understanding of the decimal number using semi-concrete aids. Figure 13 shows the mathematical activity of the whole-class discussion followed by making a comparison.

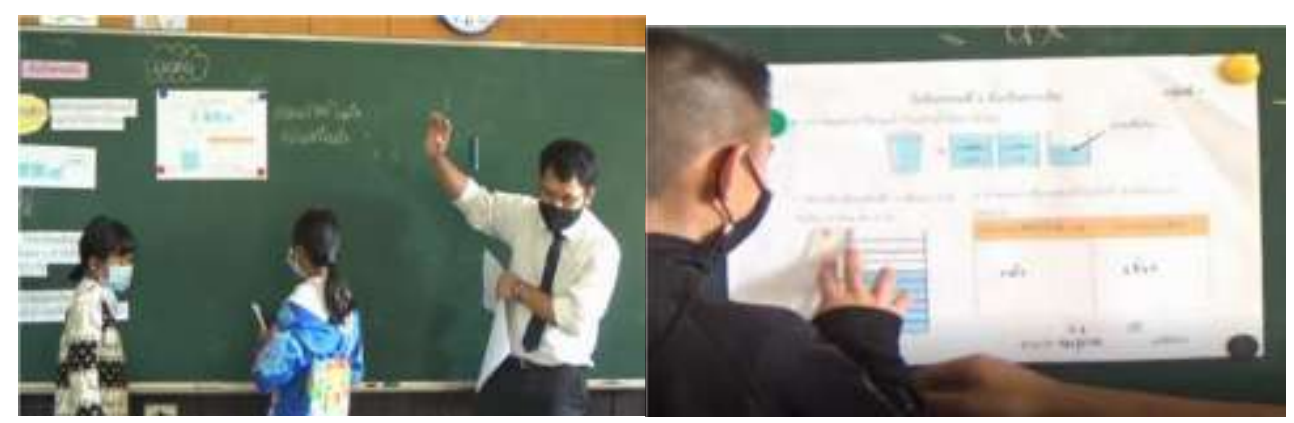

Figure 13. The activity of whole-class discussion and comparison

(iv) Summarize through connecting students' mathematical ideas that emerged in the classroom

The teacher posted their student worksheets on the magnetic board after students completed their discussion and comparison at the third stage. At the final stage of OA, students were required to explain verbally their solutions, and the teacher wrote down all the additional information on the students' worksheets. Then, the teacher summarized today's lesson by compiling all the students' ideas according to the posted student worksheets. Besides, students were encouraged to share their ideas as illustrated in Figure 14. At the end of the lesson, the teacher concluded the research lesson by emphasizing mathematical concepts of decimal numbers as shown in Figure 15.

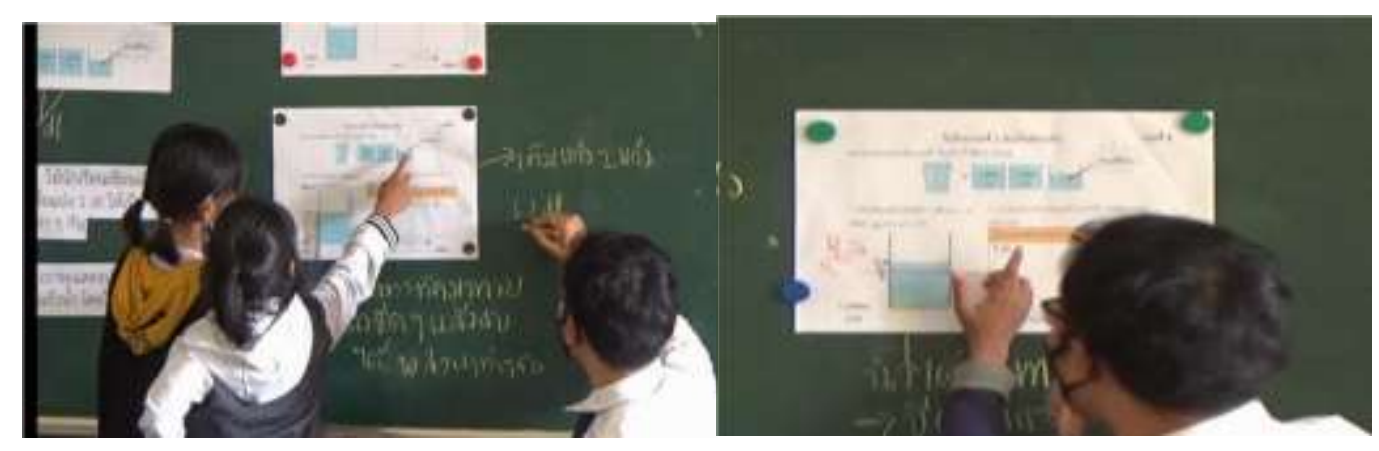

Figure 14. The activity of summarization of students' ideas 


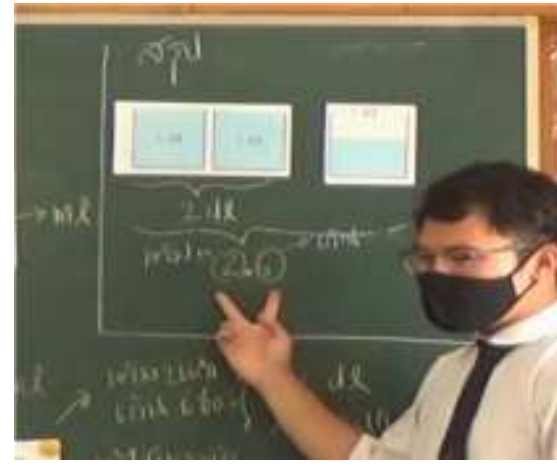

Figure 15. The teacher emphasized the key concepts of decimal number

The results of using OA at the second step of the LS process revealed that students demonstrated their mathematization in fostering their mathematical thinking to transform their ideas from the real-world to the mathematical world using semi-concrete aids. Besides, the results also indicated that students are needed appropriate planned mathematical activities to cultivate their mathematical thinking in problem-solving simultaneously.

\section{Results from Step 3 of LS: Collaboratively Reflect on Teaching Practice (See)}

A reflection session was conducted after the research lesson primarily dealing with the mathematical activities in accordance with the obtained data either from field notes or student worksheets regarding students' mathematization. The results from Step 3 of the LS showed that the LS team members identified some problems that occurred during their teaching practice. The problem that they identified is the student worksheet that showing $2 \mathrm{dl}$ and excess was found unclearly in their design. The semi-concrete aids at the excessive volume as shown in Figure 16, is a little over half of the container, so students confused either 0.5 or 0.6 . This was found to affect students' mathematization. However, researchers found that Step 3 of LS is very important because it allowed the LS team members to identify the pieces of evidence relating to students' mathematization while they participated in mathematical activities. Furthermore, the results of Step 3 can be used to promote teacher professionalism. Figure 17 shows Step 3 of LS.

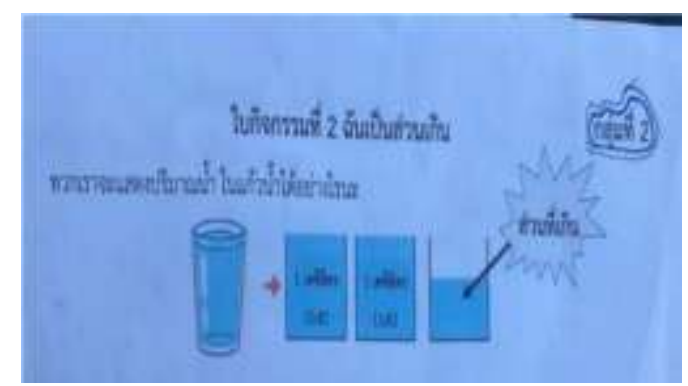

Figure 16. Students confused about the decimal number at the third container 


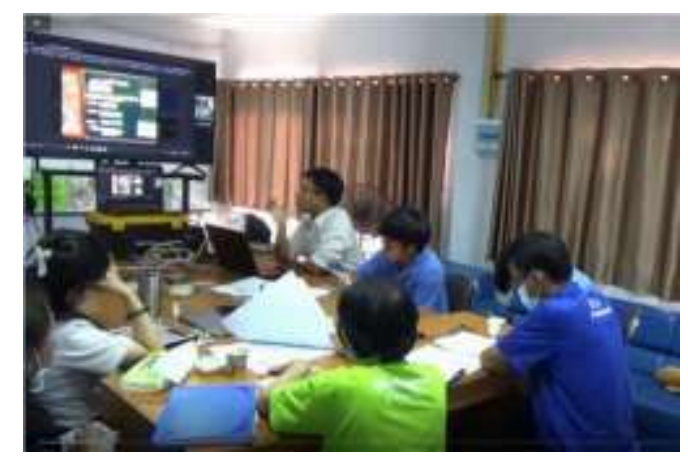

Figure 17. The Step 3 of LS

\section{CONCLUSION}

The purpose of this research was to contribute knowledge about the importance of OA treatment that could enhance students' mathematization through the creativity of LS team members in designing mathematical activities. The results confirm that the Thailand LS Model can increase teachers' ability to create a teaching situation based on students' knowledge. This result is corresponding to Lundbäck and Egerhag's (2020) results. An important limitation of this research is that it was conducted in a very specific context, and therefore, the results cannot be generalized to other situations. In conclusion, researchers would like to suggest a future study that could explore more creative mathematical activities to solve more challenging problem situations so that students are given optimal opportunities to develop their mathematical ideas in depth.

\section{ACKNOWLEDGMENTS}

This research work was supported by the Basic Research Fund of Khon Kaen University, Khon Kaen 40002, Thailand.

\section{REFERENCES}

Bevan, D., \& Capraro, M. M. (2021). Posing creative problems: A study of elementary students' mathematics understanding. International Electronic Journal of Mathematics Education, 16(3), em0654

Chikusvura, N., Sibanda, L., \& Mathwasa, J. (2021). The Competence-Based Advanced Level Mathematics Curriculum: Implications for Students' Enrolment in one University in Zimbabwe. Randwick International of Education and Linguistics Science Journal, 2(1), 8-19.

Daniels, H. (2016). Vygotsky and pedagogy. London, UK: Routledge.

Inprasitha, M. (2004). Teaching by using open approach in mathematics classroom of Japan. KKU Journal of Mathematics Education 1, p. 3

Inprasitha, N. (2009). Lesson Study: Innovation for developing teacher and students. Doctor of Education thesis. Khon Kaen, Thailand: Khon Kaen University.

Inprasitha, M. (2011). One feature of adaptive Lesson Study in Thailand: Designing a learning unit. Journal of Science and Mathematics Education in Southeast Asia, 34(1), pp. 47-66.

Inprasitha, M. (2015). New model of teacher education program in mathematics education: Thailand experience. Paper presented at the ICMI-East Asia Regional Conference on Mathematics Education, Cebu City, the Philippines, May 11-15. 
Inprasitha, M. (2017). Understanding school mathematics through analysis of mathematics textbook. Paper presented at the $27^{\text {th }}$ Intensive Seminar, Khon Kaen, Thailand: Khon Kaen University. [in Thai]

Kaewdang, R. (2000). Indigenous knowledge for a learning society. Paper presented at the $6^{\text {th }}$ UNESCO-APEID International Conference on Education, Bangkok, Thailand, December 12-15.

Khammani, T. (2012). Science of teaching: Knowledge to the effective learning process. Bangkok, Thailand: Chulalongkorn University Printing House.

Lewis, C. (2000). Lesson Study: The core of Japanese professional development. Paper presented at the American Educational Research Association (2000 Annual Meeting), New Orleans, LA.

Lundbäck, B., \& Egerhag, H. (2020). Lesson Study as a bridge between two learning contexts. International Journal for Lesson \& Learning Studies, 9(3), 289-299. https://doi.org/10.1108/IJLLS-02-2020-0006

Moonsri, A., Inprasitha, M., \& Changsri, N. (2021). Core values of graduate students in the context of Lesson Study process. International Educational Research, 4(1), pp. 38-45.

Murata, A. (2011). Introduction: Conceptual overview of Lesson Study. In Hart, L. C. et al. (Eds), Lesson Study Research and Practice in Mathematics Education, Springer, pp. 112.

Nohda, N. (2000). Teaching by open-approach method in Japanese mathematics classroom. In Proceedings of the Conference of the International Group for the Psychology of Mathematics Education (PME), Hiroshima, Japan, July 23-27, Volume 1, ERIC ED 466736

Pyper, J. S. (2021). Problem-based learning as a professional learning model helped me with the sudden demand of remote learning, and I believe is helping me offer students ownership and their own voice in their learning. Academia Letters, Article 563. https://doi.org/10.20935/AL563.

Reeves, S., Peller, J., Goldman, J., \& Kitto, S. (2013). Ethnography in qualitative educational research: AMEE guide no. 80. Medical Teacher, 35(8), e1365-e1379. https://doi.org/10.3109/0142159X.2013.804977

Sambová, L., \& Tichá, M. (2016). On the way to develop open approach to mathematics in future primary school teachers. ERIES Journal, 9(2), 37-44.

Stigler, J. W., \& Hiebert, J. (1999). The teaching gap: Best ideas from the world's teachers for improving education in the classroom. New York, NY: Summit Books.

Takahashi, A. (2006). Types of elementary mathematics Lesson Study in Japan: Analysis of features and characteristics. Journal of Japan Society of Mathematics Education, 88(8), pp. 2-14. [in Japanese]

Tall, D. (2014). Making sense of mathematical reasoning and proof. In Mathematics \& mathematics education: Searching for common ground (pp. 223-235). Springer, Dordrecht. 